\title{
Issues and Perceptions of Farmers/Herders Conflicts in Central Nigeria
}

\author{
Vahyala Adamu Tari*
}

\begin{abstract}
Farmers/herders conflict is not new in Nigeria. The need to put more emphasis on Central Nigeria particularly Benue, Plateau and Nasarawa States was born out of the persistent conflicts arising from and complicated by farmer-herder vested interest. Currently, the subject matter is under-exploited and under-researched. Existing extant studies in that regard tend to have focused on farmer-herder conflicts without comprehensively emphasizing the philosophy and ideology operating by the two parties in fueling the conflicts. The study adopts community case study approach. Three states were purposefully selected, namely Benue, Plateau and Nasarawa, these states were highly affected by the conflict in recent years. Two local governments were randomly selected from each state. individuals were selected for Key Informant Interview (KII), FGD and Study Chart from All Farmers Association of Nigeria (AFAiencN), Miyetti Allah Cattle Breeders Association of Nigeria (MACBAN), Community Security Architecture Dialogue (CSAD). Participation was voluntary, therefore, those who were readily available were used. $30 \mathrm{KII}$, 17 FGDs and 10 SCs were carried out across the targeted communities. Findings show that issues and perceptions of farmers/herders' conflict in Central Nigeria includes: divergent of perception in the process of survival; land grabbing and unending tension; water scarcity and insufficient pasturelands; underage and children herding and profiling/stereotyping. This calls for an urgent need for government at all levels including Non-Governmental Organizations (NGOs) to create effective awareness, promote peace building and other measures to curtail the existing conflict.
\end{abstract}

Key Words: Conflict, Farmers/Herders, Issues, Land, Perception

*Research Scholar, Nigeria Police Academy,Wudil,Kano State. Emai: vahyalatariadamu@gmail.com 


\section{INTRODUCTION}

In The central Nigeria has experienced escalating tension between primarily farmers and herders, these groups seek access to the region's fertile land for crops and cattle grazing. Violent confrontations between farmers and herders have become a defining feature of inter-group relations among communities in Central Nigeria. Environmental degradation, social manipulation of ethno-religious biases, profiling, stereotype and urbanization have altered relationships that were historically interdependent and mutually beneficial. Conflicts between farmers and herders exist on a large scale, within both Nigeria and the greater Lake Chad Basin and Sudano-Sahel region; however, states within Nigeria's central geo-political zone have witnessed an increase in casualties as consequences of these fractured relationships. Crop damage, attacks on cattle, rape on female farmers, cattle theft/rustling, under age herders, blockage of cattle routes, profiling and stereotype are major triggers that initiate conflicts between the two groups, which often lead to cycles of revenge attacks. ${ }^{1}$

The dislocated relationships and series of attacks and counter attacks have claimed thousands of people and displaced tens of thousands of people in central Nigeria. The challenges have resulted in wanton loss of lives, crops and cattle in the area that have the potential to feed Nigeria. According to Kwaja and Ademola-Adelehin the increased competitions for land and water resources further exacerbate everyday conflicts when they occur. ${ }^{2}$ For instance, when cattle destroy the crops of all subsistence farmers, it is a direct loss to the farmers' livelihood, and this may exacerbate pre-existing tensions between ethnic-groups of the farmers and herders are of different ethnicities, sparking broader conflict and violence. Similar examples play out for herder when cattle are attacked and killed, often in retaliation to destruction of farmland. This situation put the survival of both the herders and farmers in abeyance and they are desperately seeking for survival strategies. This study therefore examines some of the issues confronting the two land users and seeks their perspectives regarding the issues.

\section{METHODOLOGY}

\section{Research Design}

The study adopts cross-sectional survey design. The method enables the researcher to study a group of people in the population by collecting and analyzing data from only a few people that are considered to be true representatives of the entire group (population). Therefore, rather than obtaining data from the whole population in the research area, only a sample is selected from the whole through an appropriate sampling procedure.

\section{Participants and Sampling}

This study adopts a community case study approach, which according to Yin (1994) in Kwaja and Abdul is an investigation built on an empirical inquiry that investigates a contemporary phenomenon within its real-life context. ${ }^{3}$ This approach enabled this study to look within its real

\footnotetext{
${ }^{1}$ A.C.M. Kwaja \& Ademola-Adelehim, B.I. Seeking Security and Stability: An Analysis of Security Responses to farmer-herder conflict in the Middle Belt Region of Nigeria. (First Ed.) Washington DC: Search for Common Ground, 2018,p.24

${ }^{2}$ Ibid.

3 A.M.C. Kwaja \& Abdul, H., Rural Banditry and Social Conflicts in Plateau State. Abuja: Centre for Democracy and Development, 2015, p.5
} 
farmer-herder clashes in central Nigeria. Of the six states in north central Nigeria, three states were purposefully selected, namely Benue, Plateau and Nasarawa, these states were highly affected by the conflict in recent years. All local state governments (LGA) under the three states were identified; Benue has 23 (LGA), Plateau has 17 (LGA), and Nasarawa has 13 (LGA). A random selection was conducted by numbering all the (LGA) and placing the numbers in three different boxes and later randomly picked two (LGA) from each box. At the end, six (LGA) were selected; Riyom and Barkin Ladi from Plateau, Awe and Doma from Nasarawa, Agatu and Guma from Benue. These communities have witness's series of conflicts between herdsmen and farmers, so it is believed that responses from the selected communities will provide a richer insight into the problem being investigated.

After the careful and proper identification of the target population and communities, by simple random sampling within each of the localities, individuals were selected for interview, FGD and Study Chart from All Farmers Association of Nigeria (AFAN), Miyetti Allah Cattle Breeders Association of Nigeria (MACBAN), Community Security Architecture Dialogue (CSAD), all at each local government Chapter Branch and Non-Governmental Organizations such as: Search for Common Ground, APURIMAC, Mercy Corps, Face of Peace at each state chapters of the affected states, who proved to have a good working relationships with targeted communities that were sought for endorsement. These guides and cover enhanced the researchers: access to the land and relevant stakeholders for meetings with a view to eliciting the vital responses. Participation was voluntary; therefore, those who were readily available were used. $30 \mathrm{KII}, 17$ FGDs and 10 SCs were carried out across the communities targeted for this study. The languages of investigation were Hausa and English. Understanding of the terrain and culture of the people in the study communities was a huge advantage for the researcher. All respondents were assured of confidentiality before they were interviewed. They were told that their responses will be used for academic purposes only. This clarity coupled with the endorsement and presences of CSOs, NGOs and Plateau Peace Building Agency (PPBA) created favorable working grounds for this study in facilitating and eliciting quality and reliable data.

\section{Data Collection Procedure}

The strength of this research lays on the interview, Focus Group Discussion (FGD) and Study Chart (SC) carried out in the course of this investigation and that afforded the researcher on opportunity to understand the content, context and dynamics of the subject matter, with the help of Research Assistants (RAs). These RAs were originally trained and serving as informants by CSOs and NGOs interfacing in the communities. Thus, this study found their knowledge and experience of great boast to this study. The interviews were recorded with the help of a recording device; permission was sought from the respondents, and was later transcribed for reporting purposes and subsequent analysis.

\section{Data Analysis}

The qualitative analysis of interview, Focus Group Discussion (FGD) and Study Chart (SC) conduct adopts the Thematic Content Analysis (TCA). This method generates a descriptive set of

For further information, also see Kuna, J.M. \& Ibrahim, J. (ed.) Rural Banditry and Conflicts in Northern Nigeria. Abuja: Centre for Democracy and Development, 2015 
qualitative data from the interview transcripts collected through grouping and distilling interview texts, and then extracts a list of common themes; this reveals the common meanings and expressions from the set respondents. ${ }^{4}$

\section{RESULTS AND DISCUSSION}

This section presents the findings adopting 'realistic' style of reporting, according to the themes that emerged. ${ }^{5}$ Since the aim of this research was to understand the public's view, the findings from the three sampled communities not presented separately.

\section{Divergent Perception in the Process of Survival}

One of the major causes of conflict among farmers/herders in central Nigeria is the issue of conflicting ideas that hinges on economics. Such bipolar arises due to ineffective awareness between the groups. For example, during the monthly meeting on Peace Architecture Dialogue (PAD) most respondents say that there is an internal collaboration between the young farmers and herders which is more of cattle theft syndicate in the study area. They reveal that the young herders know the names of cattle and also have access to the cattle, as well as cattle's route. While the Birom, Eggon, Jukum and Tiv's youths know the markets. Conflict started when the elderly herders negatively reacted as they heard that their cattle are sold out by the young farmers without knowing that their children are also involved in the process. Similarly, the idea of open grazing also instigated conflict among farmers and herders. A participant during interview said:

There is a wrong philosophy and ideology guiding an average herder; they commonly say Daji na Allah ne which means the bush belongs to God. So, they follow the green grass. This ideology hinders them from changing their lifestyle to embrace modern pastoralism...we do not even know some of them because they come from faraway places, and we cannot allow their cattle to eat our farm plants and go free. ${ }^{6}$

An overwhelming number of participants during FGD commented that blockage of cattle routes is part of the reason for the conflict. They argue that their cattle routes have been overtaken by farmers, railways, hospitals, schools, hotels, road constructions, among others. In this regard, a herder expressed his view that:

Our cattle know their routes, once they follow a route, after many years, they would trace the route to where they take water or graze. Now that cattle routes are blocked or narrowed, we have to maneuver ways for cattle to pass or graze. In most times, such maneuvering ended up in farm trespass and subsequent conflicts. ${ }^{7}$

\footnotetext{
${ }^{4}$ Ibid.

${ }^{5}$ G. E. Gorman, Clayton, P. R., Shep, S. J., \& Clayton, A., Qualitative research for the information professional: A practical handbook. London: Facet Publishing, 2005. p. 34

${ }^{6}$ KII Participant, 2019

${ }^{7}$ FGD Participant, 2019
} 
In contrast, many farmers argue that the blockage was caused as a result of population growth which led to the emergence of agrarian capitalism enhanced by agricultural expansion policies. Although, herders also express concern about poisoning of cattle through water, cassava pills and mangoes. The farmers conclude that open grazing most times made cattle vulnerable to food poisoned. During FGD with All Farmers Association in the local chapter, a participant says:

We rear animals also; we can't poison water sources or use cassava pills or mangoes. What if our animal (goals, sheep, and dogs) drink the water or eat the poisoned cassava pills and die? More so, our traditional rulers regulate and punish any attempt of food poisoning to cattle. By whosoever...but if the herders complain of using herbicides. It is important for them to know that we have to use chemicals to control weeds in our farms and if cattle accidently eat chemicalized grasses, they may not survive. So, the herders need to control their cattle not to come close to our farmlands. ${ }^{8}$

Based on the above comments, there is very low awareness on the land ownership and other related materialism. Leo argues that although urbanization leads to improvement in facilities such as roads, earth dams, boreholes, veterinary clinics, health centers, bush fire protection, etc. but still it is obviously becoming a huge challenge to livestock mobility and production in Nigeria. ${ }^{9}$ Vaasch asserts that man at all kinds of society attaches great importance to what he owes, possesses or what he can call his own in the society and gives less attention to any given authority that will suppress his possession. ${ }^{10}$ Marx further indicates that humans by nature guide jealously what they feel naturally belongs to them and vehemently resist any attempt by others to invade or encroach; he concludes conflicts arise from the struggle over resources in the society.

\section{Land grabbing and unending tension}

Another recurrent issue related to farmers/herders' conflict is the continuation of retention of farm/land grab across the study areas. Many farmers as well as the herders claimed that their lands is been grabbed from where they used to stay before they were sent parked to Internal Displaced Persons' Camp due to violent conflicts in the past. One of the sampled community dwellers said:

Our ancestral land has been grabbed. We cannot go back to our settlements; we are clocking more than a year in Internally Displaced Persons Camp. Herder/Natives are occupying our farmlands and claiming to be theirs. Some of us who are out of the camp and even us here can't stay and watch a stranger occupying my ancestral lands. In fact, some of us bought their land with their money. ${ }^{11}$

\footnotetext{
${ }^{8}$ FGD Participant, 2019

${ }^{9}$ N.Y. Leo, Technical Assessment of Nigerian Livestock Resource Management: Past, Present and Future perspectives. Paper presented at the International Conference on Security and Development: Challenges of Pastoralists in West and Central Africa, Kaduna, 22nd $-24^{\text {th }}$ June, 2014

${ }^{10}$ G.A. Vaasch, Indigenes' or Settlers? The Geo-politics of the Tiv-Jukun Conflicts, 1976-2003, 2013. p.5

${ }^{11}$ KII Participant, 2019
} 
This issue is predominant in the Gashist community of Barkin Ladi: of Plateau State and Mahanga community, Awe L.G.A. of Nasarawa. In Awe, the land grabbed was perpetrated in communities bordering Guma and Agatu local government areas of Benue State. Interviewing respondents in Awe, they lamented that these issues were predominantly carried out by the herders who were sent out of Benue state due to the implementation of Open Grazing Prohibition and Ranches Establishment Law (OGPREL). Further investigation reveals that most of the settlers or inhabitants of the lands in the inter-border communities were Tivs whom the frustrated herders from Benue see as non-indigenes to Nasarawa state; hence the Tivs farmers should leave and go to Benue where they belong. Further inquiry regarding this issue did not stop at seizure of lands only; it involves illegal occupation and retention of houses and other assets of the fled population. As a confirmation to this, affected population in the communities were either still seeking refuge in IDPs camp or had resorted to new settlements as observed in Gashits community of Barkin Ladi L.G.A. in Plateau State and Mahanga Community of Awe L.G.A. of Nasarawa State.

Similarly, Okeke maintains that there is deprivation of lands from owners, which they would like to use for other purposes, lands they would like their children to inherit. ${ }^{12}$ Obaze further argues that the situation is not yet as grave as in Niger to Chad, which despite having more severe problems of drought and desertification, still exports cattle from Nigeria. ${ }^{13}$ After all, if you force a Fulani man not to move with his cattle, you are inviting trouble. This is likely to be true because if the government does not directly involve the value chain of cattle business, the sedentary rearing of cattle may be confronted with challenges in controlling the nature and character of herders who have been pasturing for more than two or three decades.

\section{Water Scarcity and Insufficient Pasturelands}

Struggle in accessing water and good pasturelands is now becoming a source of clash and conflict among farmers/herders. It was observed during the monthly Command and Security Architecture Dialogue (CSAD) that scarcity of water and inadequate pasturelands is attributed to climate change which resulted in desert encroachment and drought. Thus, deforestation such as felling of trees for animal feeds, sources of energy in many homes and farmland expansion is alarming. Many participants of the meeting support the claim that the receding Lake Chad Basin obviously exacerbated the long-distance movement of herders in search for water and good pasture to feed their cattle. Their movement on farms to access water and change of location for easy access to pasture lands result in conflict. In the same direction an interviewed farmer also reveals that:

The idea that only herders migrate in search for water is a fallacy. Farmers also rear cattle and other domestic animals that need water to drink. Moreover, the cin rani farmers otherwise known as dry season farmers mostly traveled a long distance to hang around river banks for irrigation farming. They are the ones used to have

\footnotetext{
12 O.E. Okeke, Conflict between Fulani Herders and Farmers in Central and Southern Nigeria: Discourse on Proposed Establishment of Grazing Routes and Reserves. An International Journal of Arts and Humanities, Vol. 3 (1). 2014

${ }^{13}$ O.H. Obaze, Political Economy of Cattle Colony in Nigeria, Paper presented in a public lecture in Nnamdi Azikiwe University (UNIZIK). 2018
} 
conflicting interests with herders who are frustrated by blockage of cattle routes leading to rivers or streams to feed their cattle. ${ }^{14}$

These comments suggest that population growth leads to lack and increase in blockage of water and pastureland/routes to herders and their cattle. Accordingly, to Homer-Dixion, environmental scarcity arises out of population growth as against its source of livelihood. ${ }^{15}$ In agreement, Elaigwu state that increased environmental scarcity caused by one or more of these factors is assumed to have several consequences, which in turn may lead to domestic armed conflicts, with intervening variables such as decreased agricultural production, decreased economic activity, migration and violent conflict. ${ }^{16}$ This kind of scarcity connotes the limited supply of grazing land, farmland and water.

\section{Underage and Child Herding}

Underage and child herding is also considered as a source of conflict. During the monthly meeting on Peace Architecture Dialogue (PAD) in Doma LGA of Nasarawa State, farmers expressed concern on perpetual use of child-herder which keeps farmlands vulnerable to trespass as most of the children found it difficult controlling the cattle or being carried away by events during grazing. Thus, frequent use of children and even girl-child assistants according to farmers resulted in beating both the cattle and the child by victimizing farmers and conflict will occur when herders' parents try to retaliate. However, the herders in several interviews revealed that their youths are more vulnerable to social vices and degrading thus, using child herding is more sufficient. For example, during FGD with herders in Awe and Barkin Ladi LGA in Nasarawa and Plateau State, one of the participant revealed that:

There is diminishing interest in pastoral duties among our youths. We have no option than to use the younger ones. Our youths are feeling too big to take out cattle. For grazing, most times even if they managed to, they end up in reckless grazing and threaten to cause harm at any resistance from the farmer and if the farmer is a woman, there are reports of physical assaults and sometimes rape. On the other side, they prefer socializing and indulging in anti-social activities such as alcoholism, drug abuse, local drug trafficking, rap banditry among others...you would observed in the evening, our youths would confidently walk into a beer parlor, take alcohol, openly womanized, perceived grazing as old fashion thus, too big to do it. Thus, in the absences of cash to maintain the standard they set for themselves they resort to cattle theft, armed robbery and kidnapping. ${ }^{17}$

\footnotetext{
${ }^{14}$ KII Participant, 2019

${ }^{15}$ T.F. Homer-Dixon, Environment, Scarcity and Violence. Princeton, NJ: Princeton University Press.1999.p.102

${ }^{16}$ J.I.Elaigwu, Security and Peace: The Imperative for National Development in Nigeria. Jos, Institute of Governance and Social Research, 2012.p. 29

${ }^{17}$ FGD Participant, 2019
} 


\section{Profiling and Stereotyping}

Another major cause of conflict among farmers/herders in the study areas is the breaking down of stereotypes in building mutual trust and promoting inter-communal co-existence for sustainable peace and development. Many respondents believe that stereotyping has led to so many unsolved issues among them. For example, during FGD a participant commented that:

There is a "we against them" syndrome at play. Even when an accident occurs, if for example a Christian is victimize by a Muslim who is riding or driving. The relatives of the victim most of the time will not try to find out the cause, they will conclude it as an international act and begin to retaliate worse fully. This stereotyping and profiling often occurs beyond borders, be it in the form of religious, workplace, tribe among others. This mutual distrust is now a norm and every incidence or situation is viewed with the lens. ${ }^{18}$

Most respondents say that profiling non-native with pejorative terms such as alien minorities, settlers or immigrants also instigate conflicts, raises suspicions and among farmers and herders in the study areas. During an interview with a farmer, he pointed out the effect of stereotyping when he said:

Stereotype has the identity of the criminal elements, and such elements successfully linked or attached their sins with their religion, political and ethnic affiliations. The resultant effects of this situation are that, bandits, cattle rustlers, rapists' armed robbers and other criminal elements took advantage of the stereotyping and profiling situation to perpetuate all manners of criminality while the longtime friends, neighbors kept killing one another in ignorance, mutual distrust and suspicion. ${ }^{19}$

\section{CONCLUSION AND RECOMMENDATIONS}

This study emphasized the fact that farmers and herders' conflict has emerged as one of the critical security issues in central Nigeria. This continuous insecurity in the region to a large extent shows elements of struggle for survival. Due to the dynamic nature of the issues, past government efforts have not been sufficient enough to tackle the complex challenges between farmers and herders. The study argued that resolving farmer-herder crisis in Central Nigeria requires a holistic and comprehensive approach that will recognize the interest and peculiarities of every locality in the study areas and the prospects of achieving that, also rests with the sincerity of purpose, genuine political will and ingenuity of relevant stakeholders in the areas of conflict/security management and farmer-herder clashes. The research did not lose sight of the fact that, the nature and manifestation of farmer-herder clashes in central Nigeria is largely economic in what was described as survival of the fittest due to stiff ecological scarcity and fierce competition for land space.

\footnotetext{
${ }^{18}$ Ibid

${ }^{19}$ KII Participant, 2019
} 
Results obtained from this study show cattle destroyed crops, farmers sometimes severely beat cattle which may lead to its death and also there is collaboration among the youths of farmers and herders in order to carry out cattle rustling and other related crimes. Thus, the Federal, State and Local Government should review and enact laws that provide instant justice for destroyed crops and for killed or rustled livestock. This should also be accompanied by laws to regulate cattle markets to ensure cattle being sold are of known regiment source and origin. Also, there should be local intervention task forces should be established by local government councils with a membership of not less than seven (07) comprising representatives of herders, farmers, traditional council, vigilante groups and NSCDC as part of the alternative disputes' resolution structure in case of any conflict.

Results also show that there is an issue of conflicting ideas hinges on economics and this is due to ineffective awareness between the groups. Thus, there is a need for the federal government to overhaul the nomadic education programme (NEP) with a view to incorporating local authorities to engage the herder audiences in alternative occupation in an attempt to curb rural banditry and conflicts in the study area.

Results obtained further indicates that the issue of profiling and stereotyping is strong among the groups. It is vital for government at all levels in collaboration with the National Orientation Agency (NOA) to have constant stakeholder engagements with the media to understand the danger of stereotyping, hate speech and profiling in the central Nigeria and promote positive narratives around farmer-herder collaborations, denounce rumors and de-escalate tension that can fuel conflicts and also inculcate the values of hard work, empathy and being a brother's keeper irrespective of their faith, tribe, religion or political affiliations.

Findings of the study further shows that underage and child herding is prevalent in the study area and it leads to conflict when the herders are carried away with situations around them and cattle astray into farms. Thus, Federal and state governments should enact laws through the legislative Houses against the phenomenon of the child-herder, night grazing, as well as institute local taskforces to oversee the implementation of the law. There should also be collaboration with relevant CSOs, NGOs to make widespread sensitization and awareness campaigns against jungle justices or taking of laws into their hands at the slightest provocation. Both parties need to be taught the habit of reporting issues to local constituted structures responsible for handling disputes relating to farmland destruction, land grabbing and cattle related issues.

Finally, the result shows that water scarcity and inadequate pasturelands also causes conflict between farmers/herders. Thus, it is important for the Federal and State Ministries of Environment and their relevant agencies to introduce tree planting campaigns in an attempt to cushion the effects of climate change variability such as desertification encroachment, drought arising from low rainfall, and sandstorms, among others. The same Ministries should as well join forces with the Ministry of Water Sources in construction of waterholes/dams and portable water for both farmers and herders and their livestock. This would reduce seasonal migration and cushion the effect of narrow corridors for grazing, routes, due to urbanization and increased livestock population. 


\section{REFERENCES}

Elaigwu, J.I., Security and Peace: The Imperative for National Development in Nigeria. Jos, Institute of Governance and Social Research.2012

Gorman, G. E., Clayton, P. R., Shep, S. J., \& Clayton, A., Qualitative research for the information professional: A practical handbook. London: Facet Publishing, 2005

Homer-Dixon, T.F., Environment, Scarcity and Violence. Princeton, NJ: Princeton University Press, 1999

Kwaja, A.C.M. \& Ademola-Adelehim, B.I., Seeking Security and Stability: An Analysis of Security Responses to farmer-herder conflict in the Middle Belt Region of Nigeria. (First Ed.) Washington DC: Search for Common Ground, 2018

Kwaja, A.M.C. \& Abdul, H., Rural Banditry and Social Conflicts in Plateau State, Abuja: Centre for Democracy and Development, 2015

Leo, N.Y. Technical Assessment of Nigerian Livestock Resource Management: Past, Present and Future perspectives. Paper presented at the International Conference on Security and Development: Challenges of Pastoralists in West and Central Africa, Kaduna, 22nd 24th June. , 2014

Obaze, O.H., Political Economy of Cattle Colony in Nigeria. Paper presented in a public lecture in Nnamdi Azikiwe University (UNIZIK), 2018

Okeke, O.E., Conflict between Fulani Herders and Farmers in Central and Southern Nigeria: Discourse on Proposed Establishment of Grazing Routes and Reserves. An International Journal of Arts and Humanities, Vol. 3 (1). 2014

Vaasch, G.A., Indigenes' or Settlers? The Geo-politics of the Tiv-Jukun Conflicts, 1976-2003., 2013 